\title{
Authors' response: Meningococcal vaccine antigen diversity in global databases
}

C Brehony $^{1}$, DM Hill ${ }^{1}$, J Lucidarme ${ }^{2}$, R Borrow $^{2}$, MC Maiden ${ }^{1}$

1. Department of Zoology, University of Oxford, South Parks Road, Oxford, United Kingdom

2. Meningococcal Reference Unit, Public Health England, Manchester Royal Infirmary, Manchester, United Kingdom

Correspondence: Carina Brehony (carina.brehony@nuigalway.ie)

Citation style for this article:

Brehony C, Hill DM, Lucidarme J, Borrow R, Maiden MC. Authors' response: Meningococcal vaccine antigen diversity in global databases. Euro Surveill.

2016;21(15): pii=30192. DOI: http://dx.doi.org/10.2807/1560-7917.ES.2016.21.15.30192

Article submitted on 11 April 2016 / accepted on 13 April 2016 / published on 14 April 2016

To the editor: We concur with Anderson et al. [1] that estimates of the coverage of the protection elicited by novel meningococcal protein vaccine formulations are dependent on knowledge of cross-reactivity. Indeed, we stressed this point in our penultimate paragraph of our article [2], where we referenced the surrogate assays developed by two companies to address this issue for their particular formulations.

For this reason, in our report [2] we were careful to discuss exact peptide matches and not strain coverage of any formulation. As Anderson and colleagues rightly state, in the absence of Phase III trial data, knowledge of the actual strain coverage of any particular commercial formulation will require post-implementation surveillance information. It remains an especial concern, however, that the greatest uncertainty concerning the cross-reactivity of these vaccines is in infants (those under 18 months of age), the age group most at risk of meningococcal disease in Europe.

Conflict of interest

None declared.

Authors' contributions

All authors participated in drafting the letter.

\section{References}

1. Anderson AS, Eiden JJ, Perez JL, Balmer P, York LJ, Jansen KU. Letter to the editor: Importance of serum bactericidal activity for estimating the breadth of protection for new meningococcal vaccines. Euro Surveill. 2016; Euro Surveill. 2016;21(15):30191. DOI: http://dx.doi.org/10.2807/1560-7917.ES.2016.21.15.30191

2. Brehony C, Hill DM, Lucidarme J, Borrow R, Maiden MC.

Meningococcal vaccine antigen diversity in global databases.

Euro Surveill. 2015;20(49):30084. DOI: 10.2807/1560-7917.

ES.2015.20.49.30084 PMID: 26676305
License and copyright

This is an open-access article distributed under the terms of the Creative Commons Attribution (CC BY 4.0) Licence. You may share and adapt the material, but must give appropriate credit to the source, provide a link to the licence, and indicate if changes were made.

This article is copyright of the authors, 2016. 